\title{
Arylsulphatase from Alteromonas carrageenovora
}

\author{
Tristan Barbeyron, Philippe Potin, Christophe Richard, Olivier Collin and \\ Bernard Kloareg
}

Centre d'Etudes d'Océanologie et de Biologie marine, CNRS UPR 9042, Station Biologique, Place George Teissier BP 74, 29682 Roscoff Cedex, France

\author{
Author for correspondence: Tristan Barbeyron. Tel: +33982923 23. Fax: +3398292324. \\ e-mail: Barboun@sb-roscoff.fr
}

Keywords: Alteromonas carrageenovora, arylsulphatase, glycosulphohydrolase, hydrophobic cluster analysis

\section{INTRODUCTION}

Arylsulphatase (aryl-sulphate sulphohydrolase, EC 3.1.6.1), an enzyme involved with the metabolism of organic sulphur and sulphate, catalyses the hydrolysis of phenolic ester sulphates such as methylumbelliferyl sulphate (MUF-S) or $p$-nitrophenyl-sulphate, as follows: $\mathrm{H}_{2} \mathrm{O}+$ Aryl-O-SO $-\stackrel{2}{-}$ Aryl-OH $+\mathrm{SO}_{4}^{2-}+\mathrm{H}^{+}$.

In aerobic soils, which are poor in inorganic sulphate, arylsulphatases are thought to provide bacteria with sulphate, by catalysing the hydrolysis of such arylsulphate esters as 2-hydroxy-5-nitrophenylsulphate and phenylsulphate from humic and fulvic acids (Fitzgerald, 1976). In both soil bacteria, such as Pseudomonas strain C12B (George \& Fitzgerald, 1981), and enteric bacteria, such as Klebsiella aerogenes (Rammler et al., 1964; Adachi et al., 1975; Murooka et al., 1978; Oka et al., 1980) and Salmonella typhimurium (Henderson \& Milazzo, 1979), as well as in

Abbreviations: ASW, artificial sea water; HCA, hydrophobic cluster analysis; IEF, isoelectric focalization; MUF, 4-methylumbelliferone; MUF-S, 4-methylumbelliferyl sulphate.

The EMBL and Swiss-Prot accession numbers for the sequence reported in this paper are X65709 and P28607 (ARS_ALTCA), respectively. the green alga Chlamydomonas reinhardtii (De Hostos et al., 1988), expression of arylsulphatase is strongly inhibited by the presence of sulphate or organic sulphur. In the marine environment, which is abundant in sulphate ions, an arylsulphatase activity not inhibited by sulphate was reported in the bacterium Alcaligenes metalcaligenes (Fitzgerald, 1976). In addition an arylsulphatase, active on phloroglucinol sulphate esters and partially inhibited by sulphate, was purified to homogeneity from the brown alga Cystoseira tamariscifolia (Knöss \& Glombitza, 1993). The enzyme from Pseudomonas strain C12B was purified to homogeneity (George \& Fitzgerald, 1981) and the arylsulphatase gene from $K$. aerogenes was cloned and sequenced (Murooka et al., 1990). Several eukaryotic arylsulphatase genes have also been described. They include arylsulphatases from the sea urchins Hemicentrotus pulcherrimus (Sasaki et al., 1987, 1988) and Strongylocentrotus purpuratus (Yang et al., 1989), and from C. reinbardtii (De Hostos et al., 1989). In addition nucleotide sequences of other sulphatases with arylsulphatase activity are known, e.g. the human lysosomal arylsulphatases $A$ (cerebrosidesulphatase, EC 3.1.6.8) (Stein et al., 1989a), and B (Nacetylgalactosamine-4-sulphatase, EC 3.1.6.12) (Peters et al., 1990) as well as human arylsulphatase C (steryl- 
sulphate sulphohydrolase, EC 3.1.6.2), a membranebound, microsomal enzyme (Stein et al., 1989b; Yen et al., 1987).

We report here on the presence of a functionally active arylsulphatase in Alteromonas carrageenovora, a marine aerobic Gram-negative bacterium (Akagawa-Matsushita et al., 1992) known to hydrolyse carrageenans, the sulphated galactans of red algae (Johnston \& McCandless, 1973; Weigl et al., 1966; Yaphe \& Baxter, 1955; McLean \& Williamson, 1979a), and to desulphate oligo kappacarrageenans (Weigl \& Yaphe, 1966; McLean \& Williamson, 1979b, 1981). We describe the cloning, nucleotide sequence and expression of the arylsulphatase of $A$. carrageenovora and discuss its possible functional relationships with two proteins identified in pathogenic bacteria involved with degradation of human tissues, Mycobacterium leprae and Porphyromonas gingivalis.

\section{METHODS}

Bacterial strains and culture conditions. $A$. carrageenovora (ATCC 43555) was obtained from the American Type Culture Collection and was grown in Zobell Medium (Zobell, 1941) at $25^{\circ} \mathrm{C}$, or in artificial sea water (ASW), consisting of $25 \mathrm{~g} \mathrm{NaCl}$ $\mathrm{l}^{-1}, 0.5 \mathrm{~g} \mathrm{MgCl}_{2} \mathrm{l}^{-1}, 0 \cdot 1 \mathrm{~g} \mathrm{CaCl}_{2} \mathrm{l}^{-1}, 1 \mathrm{~g} \mathrm{KCl} \mathrm{l}^{-1}, 1 \mathrm{mg} \mathrm{FeCl}_{2} \mathrm{l}^{-1}$ and $12 \mathrm{mM}$ phosphate buffer ( $\mathrm{pH} 8 \cdot 5)$. When appropriate ASW was supplemented with $5 \mathrm{~g}$ galactose $\mathrm{l}^{-1}, 1 \mathrm{~g} \mathrm{NH}_{4} \mathrm{Cl} \mathrm{l}^{-1}$ or $1 \mathrm{~g}$ $\mathrm{NaNO}_{3} \mathrm{l}^{-1}, 1 \mathrm{mM}$ cysteine or $\mathrm{Na}_{2} \mathrm{SO}_{4}$. E. coli strain DH5 $\alpha[\mathrm{rec} A 1$ end $A 1$ gyr $A 96$ thi1 hsdR $17\left(\mathrm{r}_{\mathrm{K}}^{-} \mathrm{m}_{\mathrm{K}^{+}}\right)$, supE44 relA1 lac $Z$ MM15] was grown on Luria-Bertani medium (LB) at $37^{\circ} \mathrm{C}$ (Maniatis $e t$ al., 1982). When appropriate, ampicillin (LBA) or tetracycline (LBT) was added to solid or liquid medium at $50 \mu \mathrm{g} \mathrm{ml}^{-1}$ or $15 \mu \mathrm{g} \mathrm{ml}^{-1}$, respectively.

Cloning and sequencing of the arylsulphatase gene. Preparation of the genomic library from $A$. carrageenovora was described previously (Barbeyron et al., 1994). The recombinant clones were inoculated for $18 \mathrm{~h}$ at $37^{\circ} \mathrm{C}$ in microtitration plates in LBA medium, supplemented with MUF-S $\left(50 \mu \mathrm{g} \mathrm{ml}^{-1}\right)$. Wells containing positive arylsulphatase clones exhibited fluorescence under UV light (366 nm), owing to the release of 4-methylumbelliferone (MUF) into the culture medium.

Plasmid DNA was isolated by the alkaline lysis method (Birnboim \& Doly, 1979) and mapped with restriction endonucleases. Restricted fragments from two of the positive recombinant plasmids (pSA3 and pSA4) were recovered onto $\mathrm{Na} 45$ Schleicher \& Schuell DEAE nylon paper and subcloned into phagemid pBluescriptII KS(-) (Stratagene). Sequencing was carried out using the dideoxy-sequencing method (Sanger et al., 1977). Sequence similarities were investigated throughout the NCBI data bank and further analysed using the hydrophobic cluster analysis program (HCA) (Dorian).

Arylsulphatase assay. The MUF-S stock solution was made in formamide at the concentration of $25 \mathrm{mg} \mathrm{m}^{-1}$ and stored at $4{ }^{\circ} \mathrm{C}$ in the dark. Aliquots of homogenous cell suspensions or cell extracts $(5-20 \mu \mathrm{l})$ were mixed with $1 \mathrm{ml}$ reaction buffer $(20 \mathrm{mM}$ Tris/ $\mathrm{HCl}, \mathrm{pH} 8 \cdot 5,500 \mathrm{mM} \mathrm{NaCl}, 10 \mathrm{mM} \mathrm{CaCl}_{2}$ ), supplemented with $50 \mu \mathrm{g}(170 \mathrm{nmol}) \mathrm{MUF}-\mathrm{S}$ and MUF production was measured at $360 \mathrm{~nm}$. Enzyme activities are expressed in nmol MUF released per min.

Production of arylsulphatase by cultures of $A$. carrageenovora and $E$. coli recombinant clones was estimated as follows: the $\mathrm{OD}_{580}$ of stationary-phase cultures was measured and the culture medium $(10 \mathrm{ml})$ was centrifuged at $2000 \mathrm{~g}$ for $10 \mathrm{~min}$; supernatants were concentrated 10 -fold. The bacterial pellet was washed and resuspended with $1 \mathrm{ml}$ reaction buffer. Aliquots $(100 \mu \mathrm{l})$ of cell suspensions and of concentrated supernatants were mixed to $0.9 \mathrm{ml}$ with reaction buffer supplemented with $45 \mu \mathrm{g}$ MUF-S, and assayed for production of MUF. To allow for comparison between different culture conditions, enzyme activies were referred to the $\mathrm{OD}_{580}$ of the initial culture.

Partial purification and analysis of arylsulphatases. Pellets from 3 l cultures of $A$. carrageenovora grown overnight in Zobell medium were lysed with a French press (Aminco) at $13 \mathrm{MPa}$ and extracted in $50 \mathrm{mM}$ Tris/ $\mathrm{HCl}, \mathrm{pH} 7 \cdot 2,10 \mathrm{mM} \mathrm{MgCl}_{2}, 10 \mathrm{mM}$ $\mathrm{NaCl}$ and $3 \mathrm{mM} \mathrm{CaCl}_{2}$. Debris were removed by centrifugation at $10000 \mathrm{~g}$. Proteins from $100 \mathrm{ml} \mathrm{E.} \mathrm{coli} \mathrm{cultures} \mathrm{grown}$ overnight in LBA medium supplemented with $50 \mathrm{mM}$ Tris/ $\mathrm{HCl}$, pH 7.2, $10 \mathrm{mM} \mathrm{MgCl}_{2}, 5 \mathrm{mM} \mathrm{KCl}, 3 \mathrm{mM} \mathrm{CaCl}_{2}$, with or without $25 \mu \mathrm{g}$ MUF-S ml ${ }^{-1}$ were extracted as described above. Crude cell extracts from either $A$. carrageenovora or recombinant E. coli were mixed with Heparin-Sepharose CL 6B (Pharmacia) suspended in $25 \mathrm{mM}$ Tris/ $\mathrm{HCl} \mathrm{pH} 8.5,5 \mathrm{mM} \mathrm{CaCl}_{2}, 1 \mathrm{mM}$ benzamidin and $1 \mathrm{mM}$ PMSF. The affinity phase was packed into a column $(1 \times 5 \mathrm{~cm})$ and proteins were eluted by Tris $/ \mathrm{HCl}$ buffer ( $25 \mathrm{mM}, \mathrm{pH} 7 \cdot 5$ ), containing $1 \mathrm{M} \mathrm{NaCl}, 1 \mathrm{mM}$ benzamidin and $1 \mathrm{mM}$ PMSF. Sulphatase activity in the eluent was monitored with $25 \mu \mathrm{g}$ MUF-S ml ${ }^{-1}$. The active fractions were pooled, de-salted and applied to a MonoQ HR 5/5 column (Pharmacia), pre-equilibrated with $20 \mathrm{mM}$ Tris/ $\mathrm{HCl}, \mathrm{pH} 8.5$. The column was eluted with a gradient of $\mathrm{NaCl}(0-500 \mathrm{mM})$ in $20 \mathrm{mM}$ Tris/ $\mathrm{HCl}, \mathrm{pH} 8.5$. Upon chromatography through the MonoQ column, arylsulphatase activity from $A$. carrageenovora fell into two distinct fractions, at $150 \mathrm{mM}$ (fraction I) and $200 \mathrm{mM} \mathrm{NaCl}$ (fraction II), in proportions of about $1: 2$. Further fractionation and analysis of native arylsulphatase were carried out with fraction II. In E. coli recombinant clone pSXS3, only one arylsulphatase fraction was present, eluted at $200 \mathrm{mM} \mathrm{NaCl}$. The sulphatase fractions were concentrated 20 -fold and analysed by SDS-PAGE (Laemmli, 1970), using a PhastSystem (Pharmacia). SDS-polyacrylamide gels were stained with silver nitrate. Non-denaturing PAGE was performed using stacking gels and resolving gels with $6 \%(\mathrm{w} / \mathrm{v})$ and $30 \%(\mathrm{w} / \mathrm{v})$ acrylamide, respectively. After migration, the native gels were soaked with $100 \mathrm{mM}$ Tris $/ \mathrm{HCl}, \mathrm{pH} 8 \cdot 0$, first for 10 min then for $3 \mathrm{~min}$ in the same solution containing $25 \mu \mathrm{g} \mathrm{MUF-S} \mathrm{ml} \mathrm{m}^{-1}$ and MUF fluorescence was observed under UV light. The $\mathrm{pI}$ of the sulphatase was measured with an isoelectric focalization (IEF) gel using a PhastSystem (Pharmacia) developing a 3-9 $\mathrm{pH}$ range. Two IEF gels were run in parallel, one was stained with silver nitrate and the other was incubated with MUF-S.

Effect of salts and $\mathrm{pH}$ on arylsulphatase activity and $\boldsymbol{K}_{\mathrm{m}}$ determinations. The effect of sodium chloride concentration on arylsulphatase activity was estimated in Tris/ $\mathrm{HCl}$ buffer (20 mM, pH 8.0) over the range $0-1.5 \mathrm{M} \mathrm{NaCl}$. Effects of potassium, magnesium and calcium chloride were examined in the same buffer over the range $0-50 \mathrm{mM}$. The influence of $\mathrm{pH}$ was measured over the range $\mathrm{pH} 5.5-11.5$ in $500 \mathrm{mM} \mathrm{NaCl}$ and $10 \mathrm{mM} \mathrm{CaCl}$ buffered with $50 \mathrm{mM}$ sodium acetate, $\mathrm{pH} 5 \cdot 5$, $50 \mathrm{mM}$ MES buffer (pH 5.5-6.5) $50 \mathrm{mM}$ MOPS (pH 6.5-7.5),

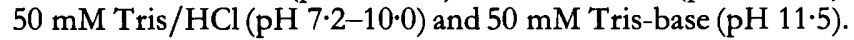
Michaelis constants $\left(K_{\mathrm{m}}\right)$ were determined using Hanes' plots with substrate concentrations ranging from $0.01-400 \mu \mathrm{M}$ in $20 \mathrm{mM}$ Tris buffer, $\mathrm{pH} 8 \cdot 0$, containing $500 \mathrm{mM} \mathrm{NaCl}$ and $10 \mathrm{mM} \mathrm{CaCl}_{2}$.

\section{RESULTS}

In 24-h-old cultures of $A$. carrageenovora MUF was readily detected upon addition of MUF-S, indicating the presence in the bacterium of an enzyme capable of hydrolysing 
Table 1. Influence of culture conditions on production of arylsulphatase by

\section{A. carrageenovora}

Cultures were initiated with the same inocula, cells were recovered at the stationary phase and supernatants and cells were assayed for sulphatase activity. Measurements were performed in triplicate and experiments were repeated once, yielding a sD below $1 \%$.

\begin{tabular}{|c|c|c|c|}
\hline Medium* & $\begin{array}{c}\text { Bacterial } \\
\text { OD }_{580} \dagger\end{array}$ & $\begin{array}{l}\text { Total activity } \\
\left(\mathrm{nmol} \mathrm{min}^{-1}\right) \dagger \dagger\end{array}$ & $\begin{array}{l}\text { Activity (nmol } \\
\mathrm{min}^{-1} \mathrm{OD}^{-1} \text { ) }\end{array}$ \\
\hline Zobell medium: supernatant & & 0.024 & 0.01 \\
\hline Zobell medium & $2 \cdot 90$ & $2 \cdot 210$ & $0 \cdot 76$ \\
\hline Zobell medium + MUF-S & $2 \cdot 89$ & $2 \cdot 000$ & $0 \cdot 69$ \\
\hline $\mathrm{ASW}+\mathrm{Gal}+\mathrm{NH}_{4} \mathrm{Cl}$ & $0 \cdot 71$ & $0 \cdot 262$ & $0 \cdot 36$ \\
\hline $\mathrm{ASW}+\mathrm{Gal}+\mathrm{NaNO}_{3}$ & $0 \cdot 13$ & $0 \cdot 410$ & 3.01 \\
\hline $\mathrm{ASW}+\mathrm{Gal}+\mathrm{NH}_{4} \mathrm{Cl}+\mathrm{Cys}$ & $1 \cdot 81$ & 0.575 & $0 \cdot 31$ \\
\hline $\mathrm{ASW}+\mathrm{Gal}+\mathrm{NH}_{4} \mathrm{Cl}+\mathrm{Na}_{2} \mathrm{SO}_{4}$ & $0 \cdot 56$ & $0 \cdot 415$ & 0.74 \\
\hline $\mathrm{ASW}+\mathrm{Gal}+\mathrm{NaNO}_{3}+\mathrm{Na}_{2} \mathrm{SO}_{4}$ & $0 \cdot 24$ & $0 \cdot 275$ & $1 \cdot 14$ \\
\hline
\end{tabular}

* ASW, artificial sea water; Gal, $1 \mathrm{~g}$ galactose $1^{-1} ; 1 \mathrm{~g} \mathrm{NH}_{4} \mathrm{Cl}^{-1} ; 1 \mathrm{~g} \mathrm{NaNO}_{3} \mathrm{l}^{-1} ; \mathrm{Na}_{2} \mathrm{SO}_{4}, 1 \mathrm{mM} ; \mathrm{Cys}$, $1 \mathrm{mM}$ cysteine.

† Stationary-phase cultures.

†† In the bacterial pellet, unless stated otherwise.

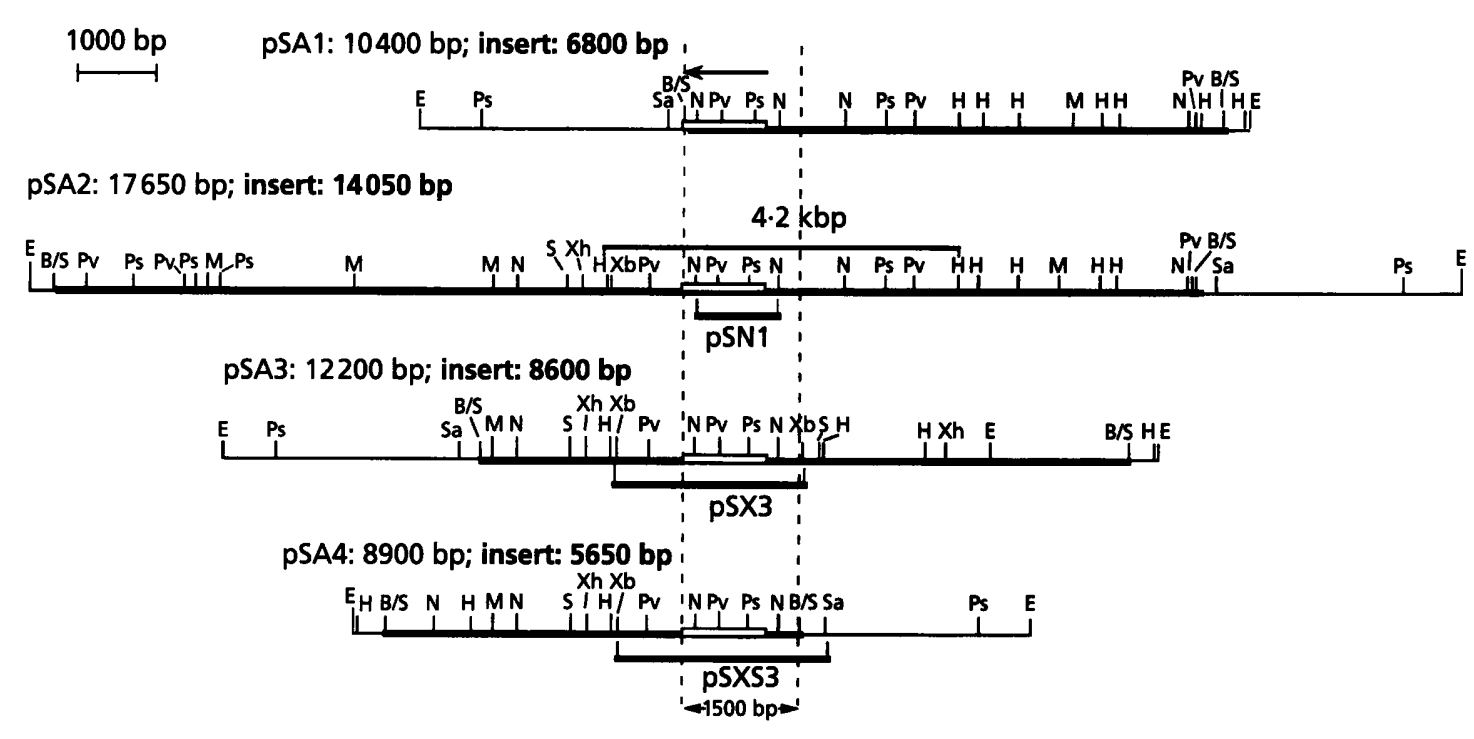

Fig. 1. Physical maps of $A$. carrageenovora genomic clones with arylsulphatase activity. Thin lines indicate the pAT153 regions, bold segments refer to $A$. carrageenovora inserts and open boxes show the arylsulphatase gene. The direction of transcription is indicated by the arrow. Dashed lines delimit the region common to all of the positive clones. The Ndel, $X$ bal and Xbal-Sall fragments, that yielded pSN1, pSX3 and pSXS3 pBluescript subclones, respectively, are shown by bold segments below the restriction maps. The HindIII fragment used for Southern hybridization is delineated above the pSA2 map. Restriction sites: E, EcoRI; B/S, BamHI-Sau3A1 junction; Ps, Pstl; Pv, Pvull; M, Mlul; N, Ndel; H, HindIII; Xb, Xbal; Xh, Xhol; S, Smal; Sa, Sall.

phenolic ester-sulphates. The activity was found in intact bacterial pellets as well as in cell lysates, whereas no significant arylsulphatase activity was detected in culture supernatants. Compared to cultures in ASW with no sulphur source, production of arylsulphatase was not inhibited when bacteria were grown in the presence of cysteine or $\mathrm{Na}_{2} \mathrm{SO}_{4}$. Activity per $\mathrm{OD}_{580}$ unit was highest with $\mathrm{NaNO}_{3}$ as sole nitrogen source. Culturing in the presence of MUF-S did not enhance the production of arylsulphatase (Table 1).

\section{Cloning of the arylsulphatase gene}

Approximately 5000 genomic clones were obtained, with a background of clones without inserts of $17 \%$. On the basis of the appearance of a luminous spot under UV 
Table 2. Production of arylsulphatase by the various recombinant $E$. coli clones grown in LBA medium

Arylsulphatase activity was assayed in cells from stationary-phase cultures. Measurements were performed in triplicate and experiments were repeated once, yielding a sD below $1 \%$.

\begin{tabular}{|lccc|}
\hline Plasmid & $\begin{array}{c}\text { Bacterial } \\
\text { OD }_{\text {580 }}\end{array}$ & $\begin{array}{c}\text { Total activity } \\
\text { (nmol } \text { min }^{-1} \text { ) }\end{array}$ & $\begin{array}{c}\text { Activity (nmol } \\
\text { min }^{-1} \text { OD }^{-1} \text { ) }\end{array}$ \\
\hline pSA1 & 5.93 & 0.20 & 0.03 \\
pSA2 & 5.68 & 6.47 & 1.14 \\
pSA3 & 5.16 & 3.43 & 0.66 \\
pSA4 & 5.37 & 8.19 & 1.52 \\
pSN1 & 7.33 & 0.00 & 0.00 \\
pSXS3 & 3.91 & 8.54 & 2.18 \\
pSX3 & 5.04 & 9.70 & 1.90 \\
\hline
\end{tabular}

light, four clones were identified as being sulphatase positive. They are referred to as $\mathrm{pSA} 1-4$.

Plasmid DNA was isolated from the four arylsulphatase clones and mapped with restriction endonucleases (Fig. 1). Inserts ranged from 5.6 to $14.0 \mathrm{kbp}$. The four plasmids shared a common $N d e I$ fragment of $1.0 \mathrm{kbp}$. Plasmids pSA3 and pSA4 were used for subcloning experiments. Only the subclones harbouring the $X b a I$ fragment (3.0 kbp) from pSA3 or the $S a l I-X b a I$ fragment $(3.0 \mathrm{kbp})$ from pSA4, which both contained the NdeI fragment, were capable of degrading MUF-S. The resulting plasmids are referred to as $\mathrm{pSX} 3$ and $\mathrm{pSXS3}$, respectively.

Arylsulphatase clones were investigated for expression of sulphatase activity upon culture in liquid LBA medium (Table 2). Compared to $A$. carrageenovora, relative expression of arylsulphatase activity in clones pSA1-4 and subclones pSXS3 and $\mathrm{pSX} 3$ was $0 \cdot 04,1 \cdot 5,1 \cdot 0,2 \cdot 0,3 \cdot 0$ and $2 \cdot 6$, respectively. Plasmid pSN1, which consisted of the NdeI fragment only (Fig. 1), did not break MUF-S down, indicating that the arylsulphatase gene is not entirely encompassed by this fragment.

\section{Biochemistry of native and recombinant arylsulphatases}

Arylsulphatase was partially purified from cell extracts of $A$. carrageenovora and of E. coli pSXS3 clone, by affinity chromatography on Heparin-Sepharose CL 6B followed by ion-exchange chromatography. The native (fraction II) and recombinant enzymes were identical in their kinetics and behaviour towards protons and salts. For both the $A$. carrageenovora and the recombinant $E$. coli partially purified arylsulphatase fractions, the $K_{\mathrm{m}}$ for MUF-S was reproducibily measured at $68 \mu \mathrm{M}$ and sulphatase activity displayed a broad optimum at $\mathrm{pH} 8.5$ and reached a plateau for $\mathrm{NaCl}$ concentrations above $500 \mathrm{mM}$. Addition of $\mathrm{KCl}, \mathrm{MgCl}_{2}$ or $\mathrm{CaCl}_{2}$ had no effect on arylsulphatase activity. Non-denaturing PAGE of the partially purified arylsulphatase fractions followed by incubation in the fluorogenic substrate showed for both $A$. carrageenovora and $E$. coli pSXS3 clone the presence of one fast-moving

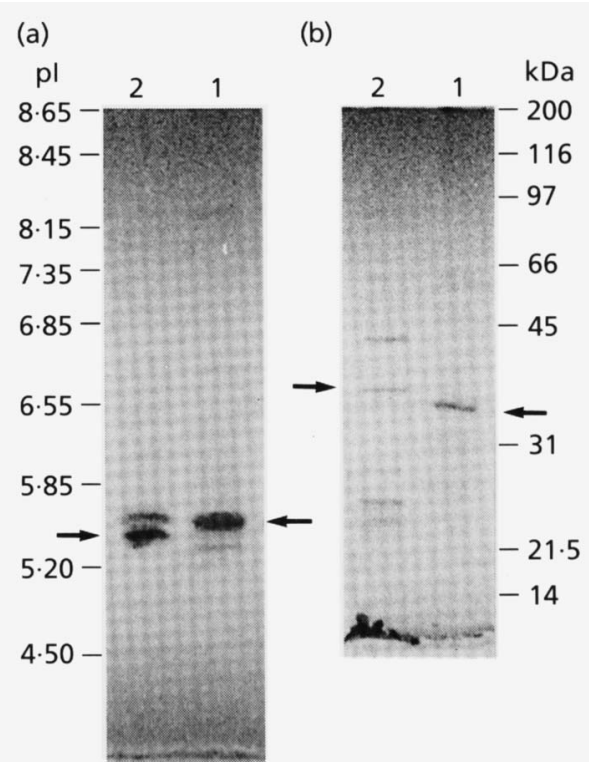

Fig. 2. Biochemical analysis of the arylsulphatases partially purified from cell extracts of $A$. carrageenovora (fraction II) (lane 1) and from E. coli pSXS3 subclone (lane 2). (a) IEF gel stained with silver nitrate. The major bands (arrows) appear at approximately pH 5.5. Incubation of a similar gel with MUF-S revealed a broad fluorescent band corresponding to the major protein bands. (b) SDS-PAGE gel stained with silver nitrate. The major bands (arrows) appear at approximately 34.0 and $36.0 \mathrm{kDa}$.

protein band, which became fluorescent upon incubation in the presence of MUF-S (not shown). IEF electrophoresis followed by staining with silver nitrate and detection with MUF-S also showed a similar $\mathrm{pI}$ for native and recombinant arylsulphatase, at approximately 5.5 (Fig. 2a). In A. carrageenovora, SDS-PAGE of the partially purified arylsulphatase fraction showed the presence of a major protein band, at approximately $34.0 \mathrm{kDa}$, and of a minor band, at $36.0 \mathrm{kDa}$ (Fig. 2b). In E. coli pSXS3 clone, an inversed pattern was obtained with the major band at $36 \cdot 0 \mathrm{kDa}$ and the minor one at $34.0 \mathrm{kDa}$.

\section{Nucleotide sequence analysis of the arylsulphatase gene}

Plasmids pSN1 and pSXS3 were sequenced in both strands, to determine the nucleotide sequence of the arylsulphatase gene. Translation of all six reading frames of

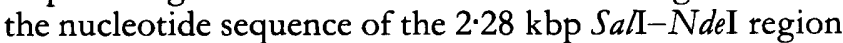
contained within the $3.0 \mathrm{kbp} S a l$ - $X b a \mathrm{I}$ fragment revealed only one ORF of $984 \mathrm{bp}$, which covers the region starting 142 bp after the first $N$ deI site up to 117 bp beyond the second NdeI site (Fig. 3). The G+C content of the sulphatase sequence, $39.7 \mathrm{~mol} \%$, falls within the range of $\mathrm{G}+\mathrm{C}$-content values characteristic of the genus Alteromonas (Baumann et al., 1972; De Vos et al., 1989), showing that the gene composition is not biased with respect to the whole genome. The sequence upstream of the start codon contains three regions that share some 


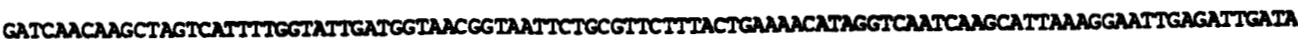

100

TTCTITATCAACTGACTGAACCACACGGATCAAAGGAAATGTCAATATCTAAAAAATGAGATTGAAGAGTTIAGTIACCTTCAAAAACACCAGACGA AGCTGTAAATGTIGTGACAGGTTGTGAACAGAAGTAAAAGCGTGACTGATGGGGAGCCCACATATAATGTAGACTGTTCAGGTAAGGAGGCAGAAAC TCGCCATCACITTCTITAACTECAAGXITAACCATHACITAGAGTTIGAAAATGGTAITCGCCATCAGTGTCTCTTGATGCTCGTTACCGCGACEAAC $-35$ $-10$

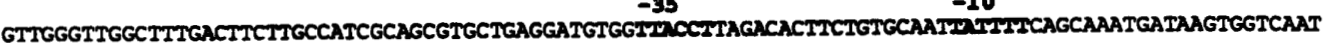
RdeI

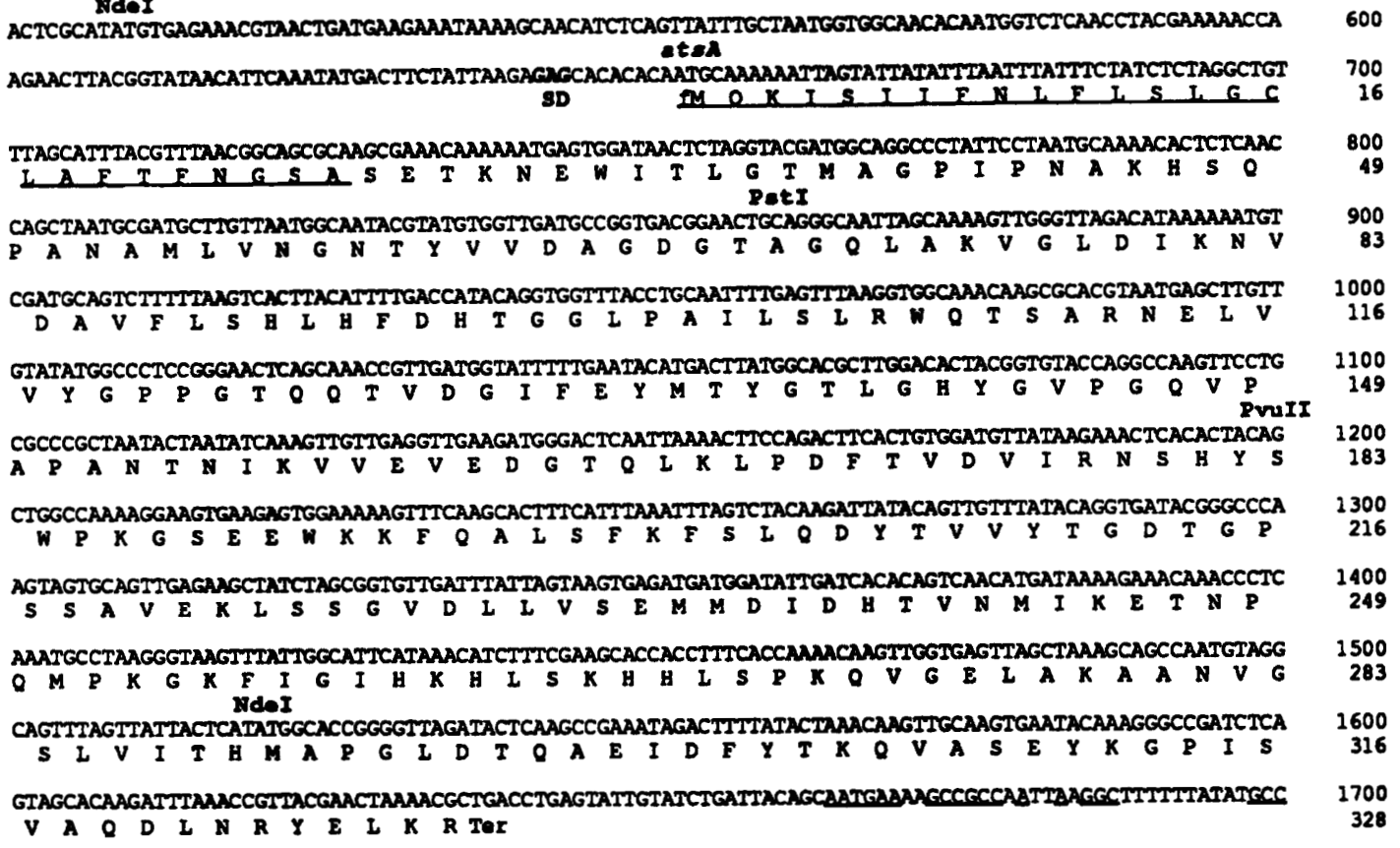

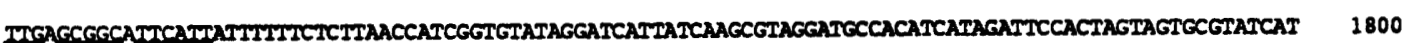

AAGGAAGTGAACTACCITIAATCATGTIIIIGTGCATGTATGTIAGCAAATITITIGCGTNMNTAGCACGCTGAGTICCTITCAGTGTGTAAAT

Fig. 3. Nucleotide and deduced amino acid sequences of the arylsulphatase gene from $A$. carrageenovora (atsA). The coding region starts at nucleotide 652 , which is 142 bp downstream from the first $N$ del site, and ends at nucleotide 1635 , $117 \mathrm{bp}$ downstream of the second $N$ del site. Putative ' $-35^{\prime}$ and ' $-10^{\prime}$ sequences for the promoter and the potential Shine-Dalgarno (SD) sequence are indicated in bold. The six T residues starting at nucleotide 1718 are likely to be the transcription termination site. The regions with possible diad symmetry are underlined. A putative 25 amino acid signal peptide is underlined. Restriction sites are shown above the nucleotide sequence.

homology with known $E$. coli consensus sequences for promoters and RBSs. A putative Shine-Dalgarno sequence, $\mathrm{GAG}$, is located $7 \mathrm{bp}$ upstream from the ATG initiation codon. Upstream (160 bp) from this ShineDalgarno sequence, the TATtt T and T'TacCt sequences could correspond to the ' -10 ' and ' -35 ' of a putative promoter of the gene of $A$. carrageenovora (Harley \& Reynolds, 1987). An area of stem-loop formation, $25 \mathrm{bp}$ downstream of the TGA stop codon, may act as a site for transcription termination (Rosenberg \& Court, 1979). The free energy associated with this stem-loop stucture is estimated to be $-24.8 \mathrm{kcal} \mathrm{mol}^{-1}\left(-103.8 \mathrm{~kJ} \mathrm{~mol} \mathrm{~mol}^{-1}\right)$ (Tinoco et al., 1973), a physiologically consistent value. Moreover, this hairpin structure is followed by six $\mathrm{T}$ residues, a sequence representative for a rho-independent termination site (Rosenberg \& Court, 1979).

The predicted translation product of the sulphatase gene is a protein of 328 amino acid residues, with a theoretical molecular mass of $35797 \mathrm{Da}$. As indicated by hydropathy analysis (not shown), the $\mathrm{NH}_{2}$-terminal end of the protein stands out as a domain of 25 amino acids with a high hydrophobicity. This domain is likely to represent the signal peptide (von Heijne, 1985), with peptidase processing of the pre-protein at the peptide bond between residues 25 (alanine) and 26 (serine).

The arylsulphatase from $A$. carrageenovora displays no significant sequence similarity with arylsulphatases from Enterobacteriacae (Murooka et al., 1990), from the green alga $C$. reinbardtii (De Hostos et al., 1989) or from sea urchins (Sasaki et al., 1988; Yang et al., 1989). It shares, however, some amino acid identity (25 and 20\%, respectively) with the so-called arylsulphatase from $M$. leprae (GenBank U00014) as well as with a $33.5 \mathrm{kDa}$ gene product of unknown function (referred to as $33.5 \mathrm{~K}$.pep), from the periodontopathogenic bacterium $P$. gingivalis (G. Rigg, personal communication). As illustrated in Fig. 4, HCA did delineate several identical hydrophobic domains along the secondary structures of these proteins, notably from amino acid residues 80-100, 220-230 and 275-295 (numbering of the $A$. carrageenovora sequence). 


\section{A. carrageenovora}
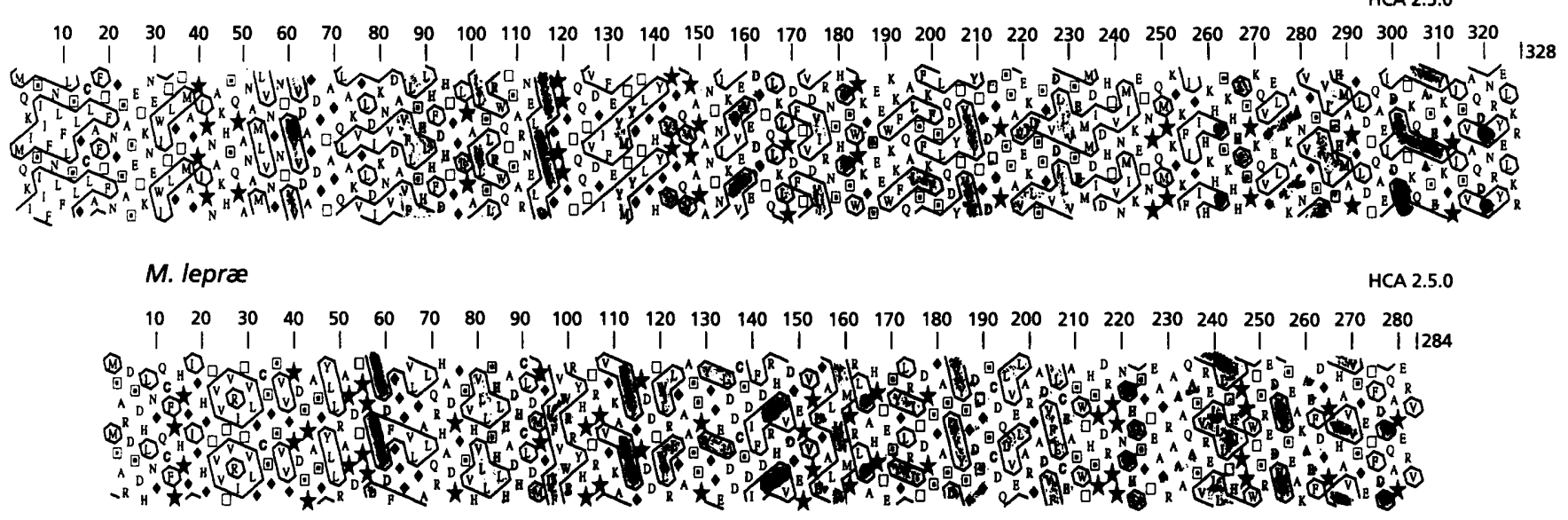

Fig. 4. HCA plots of arylsulphatases from $A$. carrageenovora and $M$. leprae. In these plots, the clusters formed by contiguous hydrophobic residues are drawn. Shaded areas highlight the conserved hydrophobic clusters, delineating analogous domains, notably from residues 80-100, 220-230, and 275-295 (numbering of A. carrageenovora). The topologically conserved hydrophilic amino acids are shaded.

\section{DISCUSSION}

As shown by the breaking down of MUF-S by cell pellets and extracts, $A$. carrageenovora synthesizes an arylsulphatase. In arylsulphatase assays with unbroken bacterial pellets, MUF was readily detected in the reaction medium. However, the enzyme was not present in significant amounts in culture supernatants. These observations suggest a periplasmic-space or an externalmembrane location of the protein, as described for Pseudomonas strain C12B (Fitzgerald \& George, 1977). This is consistent with hydropathy analysis of the protein deduced from the nucleotide sequence, which shows the presence of a signal peptide.

We have identified the structural gene of the arylsulphatase from $A$. carageenovora by functional cloning into $E$. coli. To our knowledge this is the first report of the gene sequence of an arylsulphatase from a marine bacterium. The recombinant enzyme had kinetic characteristics identical to the native protein. Rather than showing the existence of a second arylsulphatase gene, the differences observed in the physical maps of pSA2 and pSA3 (Fig. 1) are probably due to ligation of two different Sau3A1 inserts in the latter plasmid. This hypothesis was confirmed by Southern blot analysis (data not shown), in which the arylsulphatase probe hybridized with one $4.2 \mathrm{kbp}$ HindIII fragment only, consistent with the pSA2 map. Compared to $A$. carrageenovora, overproduction of arylsulphatase by pSA2, pSA4, pSXS3 and pSX3 is likely to be due to a high copy-number of recombinant vectors. By contrast, the pSA1 clone exhibited a 20 -fold shiftdown of the activity, suggesting that sequences downstream of the arylsulphatase gene positively regulate its expression. Similarly, pSA3 did not overproduce aryl- sulphatase, showing that the putatively artefactual insert upstream of the gene reduced the production of the protein in this clone. Translation of the ORF results in a protein of $35.8 \mathrm{kDa}$. Partially purified arylsulphatase fractions from recombinant $E$. coli contained a major protein band, with an apparent molecular mass of $36.0 \mathrm{kDa}$, consistent with the above value, as well as a minor band with a slightly smaller molecular mass, about $34.0 \mathrm{kDa}$. In arylsulphatase from $A$. carrageenovora, however, a major band was detected by SDS-PAGE at $34 \cdot 0 \mathrm{kDa}$ whereas a minor band was detected at $36 \cdot 0 \mathrm{kDa}$. Similarly, double bands with arylsulphatase activity were detected in IEF gels. These results as well as the presence of a signal peptide of 25 amino acids suggest that the primary translation product is processed down to a mature protein of 304 amino acids, with a theoretical molecular mass of $33100 \mathrm{Da}$. We assume that this processing was not as significant in the recombinant $E$. coli clone.

Similarly to the marine bacterium Alc. metalcaligenes (Fitzgerald, 1976), production of arylsulphatase in $A$. carageenovora is not repressed by sulphate ions or cysteine, a finding consistent with the presence of large amounts of sulphate in sea water. Since arylsulphatase from $A$. carrageenovora is probably not essential for providing the bacterium with sulphur, one may therefore ask what is the physiological function of this constitutive enzyme in A. carageenovora. A likely possiblity, consistent with the ecology of this bacterium, is involvement with desulphatation of seaweed compounds for use as carbon sources. However, no sulphohydrolase activity was observed upon incubation of brown algal phloroglucinol monosulphate and diphtorethol disulphate in the presence of $A$. carrageenovora arylsulphatase (W. Knöss \& $\mathrm{K}$.-W. Glombitza, personal communication). The arylsulphatase 
from $A$. carrageenovora was also incapable either of removing sulphate from neocarrabiose-4-O-sulphate or from neocarratetraose-4-O-sulphate (data not shown), indicating that the enzyme is not functionally related to the $55 \mathrm{kDa}$ glycosulphatase previously characterized in this bacterium (McLean \& Williamson, 1979b). As A. carrageenovora was reported to also degrade sulphated fucans from brown algae (Yaphe \& Morgan, 1959), we are currently assessing the possibility that sulphated oligofucans are the physiological substrate of arylsulphatase.

The protein sequence of arylsulphatase from $A$. carrageenovora displays no significant similarity to the microbial arylsulphatases repressed by sulphate (De Hostos $e t$ al., 1989; Murooka et al., 1990) nor to the animal proteins reported with arylsulphatase activity (Peters $e t$ al., 1990; Sasaki et al., 1988; Stein et al., 1989a, b; Yang et al., 1989). Interestingly, however, HCA plots indicate that the arylsulphatase of $A$. carrageenovora and two protein sequences, from the pathogenic bacteria $P$. gingivalis and $M$. leprae, respectively, share domains with identical 3-D foldings. Since the two latter bacteria both cause diseases that affect the extracellular matrix, it is tempting to speculate that these proteins are glycosulphohydrolases, involved with the breakdown of sulphated glycosaminoglycans.

\section{ACKNOWLEDGEMENTS}

We are grateful to Dr W. Knöss and Professor K.-W. Glombitza (Bonn) for assessing arylsulphatase for activity on algal sulphated polyphenols and to Dr G. Rigg (Leicester) for sharing unpublished sequence data. We thank G. Gugglielmi and C. Astier for helpful suggestions on the manuscript.

\section{REFERENCES}

Adachi, T., Murooka, Y. \& Harada, T. (1975). Regulation of arylsulfatase synthesis by sulfur compounds in Klebsiella aerogenes. J Bacteriol 121, 29-35.

Akagawa-Matsushita, M., Matsuo, M., Koga, Y. \& Yamasato, K. (1992). Alteromonas atlantica sp. nov. and Alteromonas carrageenovora sp. nov., bacteria that decompose algal polysaccharides. Int J Syst Bacteriol 42, 621-627.

Barbeyron, T., Henrissat, B. \& Kloareg, B. (1994). The gene encoding the kappa-Carrageenase of Alteromonas carrageenovora is related to beta-1,3-1,4-glucanases. Gene 139, 105-109.

Baumann, L., Baumann, P., Mandel, M. \& Allen, R. D. (1972). Taxonomy of aerobic marine eubacteria. J Bacteriol 110, 402-429.

Birnboim, H. C. \& Doly, J. (1979). A rapid alkaline extraction procedure for screening recombinant plasmid DNA. Nucleic Acids Res 7, 1513-1523.

De Hostos, E. L., Togasaki, R. K. \& Grossman, A. (1988). Purification and biosynthesis of a derepressible periplasmic arylsulfatase from Chlamydomonas reinbardtii. J Cell Biol 106, 29-37.

De Hostos, E. L., Schilling, J. \& Grossman, A. R. (1989). Stucture and expression of the gene encoding the periplasmic arylsulfatase of Chlamydomonas reinhardtii. Mol \& Gen Genet 218, 229-239.

De Vos, P., Van Landschoot, A., Segers, P., Tytgat, R., Gillis, M., Bauwens, M., Rossau, R., Goor, M., Pot, B., Kersters, K., Lizzaraga, P. \& de Ley, J. (1989). Genotypic relationships and taxonomic localisation of unclassified Pseudomonas and Pseudomonas-like strains by deoxyribonucleic acid: ribosomal ribonucleic acid hybridizations. Int J Syst Bacteriol 39, 35-49.

Fitzgerald, J. W. (1976). Sulfate ester formation and hydrolysis: a potentially important yet often ignored aspect of the sulfur cycle of aerobic soils. Bacteriol Rev 40, 698-721.

Fitzgerald, J. W. \& George, J. R. (1977). Localization of arylsufatase in Pseudomonas C12B. Appl Environ Microbiol 34, 107-108.

George, J. R. \& Fitzgerald, J.W. (1981). Arylsulfatase from Pseudomonas sp. strain C12B : purification to homogeneity, immunological analysis, and physical properties. J Bacteriol 145, 1428-1431.

Harley, C. B. \& Reynolds, R. P. (1987). Analysis of E. coli promotor sequences. Nucleic Acids Res 15, 2343-2360.

Henderson, M. J. \& Milazzo, F. H. (1979). Arylsulfatase in Salmonella typhimurium: detection and influence of carbon source and tyramine on its synthesis. $J$ Bacteriol 139, 80-87.

von Heijne, G. (1985). Signal sequences: the limits of variation. $J$ Mol Biol 184, 99-105.

Johnston, K. H. \& McCandless, E. L. (1973). Enzymic hydrolysis of the potassium chloride soluble fraction of carrageenan: properties of 'lambda-carrageenases' from Pseudomonas carrageenovora. Can J Microbiol 19, 779-788.

Knoss, W. \& Glombitza, K. W. (1993). A phenolsulphatase from the marine brown alga Cystoseira tamariscifolia. Pbytocbemistry 32, 1119-1123.

Laemmli, U. K. (1970). Cleavage of structural proteins during the assembly of the head of bacteriophage T4. Nature 227, 680-685.

McLean, M. W. \& Williamson, F. B. (1979a). Kappa-carrageenase from Pseudomonas carrageenovora. Eur J Biochem 93, 553-558.

McLean, M. W. \& Williamson, F. B. (1979b). Glycosulphatase from Pseudomonas carrageenovora. Purification and some properties. Eur $J$ Biochem 101, 497-505.

McLean, M. W. \& Williamson, F. B. (1981). Neocarratetraose 4-Omonosulfate $\beta$-hydrolase from Pseudomonas carrageenovora. Eur $J$ Biochem 113, 447-456.

Maniatis, T., Fritsch, E. F. \& Sambrook, J. (1982). In Molecular Cloning: a Laboratory Manual. Cold Spring Harbor, NY: Cold Spring Harbor Laboratory.

Murooka, Y., Higashiura, T. \& Harada, T. (1978). Genetic mapping of tyramine oxidase and arylsulfatase genes and their regulation in intergeneric hybrids of enteric bacteria. $J$ Bacteriol 136, 714-722.

Murooka, Y., Ishibashi, K., Yasumoto, M., Sasaki, M., Sugino, H., Azakami, H. \& Yamashita, M. (1990). A sulfur- and tyramineregulated Klebsiella aerogenes operon containing the arylsulfatase (ats $A$ ) gene and the ats $B$ gene. $J$ Bacteriol 172, 2131-2140.

Oka, M., Murooka, Y. \& Harada, T. (1980). Genetic control of tyramine oxidase, which is involved in derepressed synthesis of arylsulfatase in Klebsiella aerogenes. J Bacteriol 143, 321-327.

Peters, C., Schmidt, B., Rommerskirch, W., Rupp, K., Zuhlsdorf, M., Vingron, M., Meyer, H. E., Pohlmann, R. \& Von Figura, K. (1990). Phylogenetic conservation of arylsulfatases. cDNA cloning and expression of human arylsulfatase B. $J$ Biol Chem 265, 3374-3381.

Rammler, D. H., Grado, C. \& Fowler, L. R. (1964). Sulfur metabolism of Aerobacter aerogenes. I. A repressible sulfatase. Biocbemistry 3, 224-230.

Rosenberg, M. \& Court, D. (1979). Regulatory sequences involved in the promotion and termination of RNA transcription. Annu Rev Genet 13, 319-353.

Sanger, F., Nicklen, S. \& Coulson, A. R. (1977). DNA sequencing with chain-terminating inhibitors. Proc Natl Acad Sci USA 74, 5463-5467. 
Sasaki, H., Akasaka, K., Shimada, H. \& Shiroya, T. (1987). Purification and characterization of arylsulfatase from sea urchin (Hemicentrotus pulcherimus) embryos. Comp Biochem Physiol B 88, 147-152.

Sasaki, H., Yamada, K., Akasaka, K., Kawasaki, H., Suzuki, K., Saito, A.; Sato, M. \& Shimada, H. (1988). cDNA cloning, nucleotide sequence and expression of the gene for arylsulfatase in the sea urchin (Hemicentrotus pulcherrimus) embryo. Eur J Biochem 177, 9-13.

Stein, C., Gieselmann, V., Kreysing, J., Shmidt, B., Polhmann, R., Waheed, A., Meyer, H. E., O'Brien, J. S. \& Von Figura, K. (1989a). Cloning and expression of human arylsulfatase A. J Biol Chem 264, 1252-1259.

Stein, C., Hille, A., Seidel, J., Rijnbout, S., Waheed, A., Schimdt, B., Geuze, H. \& Von Figura, K. (1989b). Cloning and expression of human steroid-sulfatase. Membrane topology, glycosylation, and subcellular distribution in BHK-21 cells. $J$ Biol Chem 264, 13865-13872.

Tinoco, I., Borer, P. N., Dengler, B., Levine, M. D., Uhlenbeck, O. C., Crothers, D. M. \& Cralla, J. (1973). Improved estimation of secondary structure in ribonucleic acid. Nature 246, 40-41.

Weigl, J. \& Yaphe, W. (1966). Glycosulfatase of Pseudomonas carrageenovora: desulfation of dissaccharide from kappa-carrageenan. Can J Microbiol 12, 874-876.

Weigl, J., Turvey, J. R. \& Yaphe, W. (1966). The enzymic hydrolysis of kappa-carrageenan with kappa-carrageenase from Pseudomonas carrageenovora. Proc Int Seaveed Symp 5, 329-332.

Yang, Q., Angerer, L. M. \& Angerer, R. C. (1989). Structure and tissue-specific developmental expression of a sea urchin arylsulfatase gene. Dev Biol 135, 53-65.

Yaphe, W. \& Baxter, B. (1955). The enzymic hydrolysis of carrageenin. Appl Microbiol 3, 380-383.

Yaphe, W. \& Morgan, K. (1959). Enzymic hydrolysis of fucoidin by Pseudomonas carrageenovora. Nature 189, 761-762.

Yen, P. H., Allen, E., Marsh, B., Mohandas, T., Wang, N., Taggart, R. T. \& Shapiro, L. J. (1987). Cloning and expression of steroid sulfatase cDNA and the frequent occurence of deletions in STS deficiency: implications for X-Y interchange. Cell 49, 443-454.

Zobell, C. E. (1941). Studies on marine bacteria. I. The cultural requirements of heterotrophic aerobes. $J$ Mar Res 4, 41-75.

Received 23 January 1995; revised 18 May 1995; accepted 30 June 1995. 